\title{
Hormone use and risk for lung cancer: a pooled analysis from the International Lung Cancer Consortium (ILCCO)
}

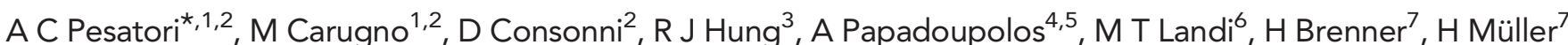
C C Harris ${ }^{8}$, E J Duell ${ }^{9}$ A S Andrew ${ }^{10}$, J R McLaughlin ${ }^{3,11}$, A G Schwartz ${ }^{12}$, A S Wenzlaff ${ }^{12}$ and I Stucker ${ }^{4,5}$

${ }^{1} E P O C A, E p i d e m i o l o g y ~ R e s e a r c h$ Center, Department of Clinical Sciences and Community Health, Università degli Studi di

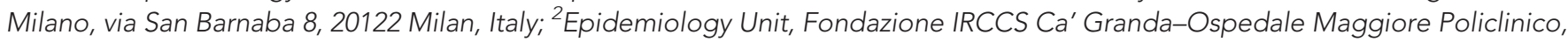
via San Barnaba 8, 20122 Milan, Italy; ${ }^{3}$ Samuel Lunenfeld Research Institute, Cancer Care Ontario Research Chair in Population Studies, Division of Epidemiology, University of Toronto, 982-600 University Avenue, M5G $1 \times 5$ Toronto, Ontario, Canada; ${ }^{4}$ INSERM, Center for research in Epidemiology and Population Health (CESP), U108, Environmental Epidemiology of cancer Team, F-94807 Villejuif, France; ${ }^{5}$ Université Paris-Sud, UMRS 1018, F-94807 Villejuif, France; ${ }^{6}$ Division of Cancer Epidemiology and Genetics, National Cancer Institute, National Institutes of Health, 9000 Rockville Pike, 20892 Bethesda, MD, USA; ${ }^{7}$ Division of Clinical Epidemiology and Aging Research, German Cancer Research Center (DKFZ), INF 581, D-69120 Heidelberg, Germany; ${ }^{8}$ Laboratory of Human Carcinogenesis, Center for Cancer Research, National Cancer Institute, National Institutes of Health, 9000 Rockville Pike, 20892 Bethesda, MD, USA; ' Unit of Nutrition, Environment and Cancer, Cancer Epidemiology Research Program, Catalan Institute of Oncology, (ICO_IDIBELL), Avda Granvia 199-203 08908 L'Hospitalet de Llobregat, Barcelona, Spain; ${ }^{10}$ Geisel School of Medicine at Dartmouth, Department of Community and Family Medicine, Section of Biostatistics and Epidemiology, One Medical Center Drive, Lebanon, NH 03756, USA; ${ }^{11}$ Public Health Ontario, 480 University Avenue, M5G 1V2 Toronto, Ontario, Canada and ${ }^{12}$ Karmanos Cancer Institute, Wayne State University, School of Medicine, 4100 John R Street, 48201 Detroit, MI, USA

Background: The association between oral contraceptive $(O C)$ use, hormone replacement therapy (HRT) and lung cancer risk in women is still debated.

Methods: We performed a pooled analysis of six case-control studies (1961 cases and 2609 controls) contributing to the International Lung Cancer Consortium. Potential associations were investigated with multivariable unconditional logistic regression and meta-analytic models. Multinomial logistic regressions were performed to investigate lung cancer risk across histologic types.

Results: A reduced lung cancer risk was found for $\mathrm{OC}$ (odds ratio $(\mathrm{OR})=0.81$; $95 \%$ confidence interval $(\mathrm{Cl})$ : $0.68-0.97)$ and $\mathrm{HRT}$ ever users $(\mathrm{OR}=0.77 ; 95 \% \mathrm{Cl}$ : 0.66-0.90). Both oestrogen only and oestrogen + progestin HRT were associated with decreased risk $(\mathrm{OR}=0.76 ; 95 \% \mathrm{Cl}: 0.61-0.94$, and $\mathrm{OR}=0.66 ; 95 \% \mathrm{Cl}: 0.49-0.88$, respectively). No dose-response relationship was observed with years of OC/HRT use. The greatest risk reduction was seen for squamous cell carcinoma $(\mathrm{OR}=0.53$; 95\% $\mathrm{Cl}$ : 0.37-0.76) in $\mathrm{OC}$ users and in both adenocarcinoma $(\mathrm{OR}=0.79 ; 95 \% \mathrm{Cl}$ : 0.66-0.95) and small cell carcinoma $(\mathrm{OR}=0.37 ; 95 \% \mathrm{Cl}$ : 0.19-0.71) in $\mathrm{HRT}$ users. No interaction with smoking status or BMI was observed.

Conclusion: Our findings suggest that exogenous hormones can play a protective role in lung cancer aetiology. However, given inconsistencies with epidemiological evidence from cohort studies, further and larger investigations are needed for a more comprehensive view of lung cancer development in women.

*Correspondence: Dr AC Pesatori; E-mail: angela.pesatori@unimi.it

Received 17 April 2013; revised 17 July 2013; accepted 4 August 2013; published online 3 September 2013

(c) 2013 Cancer Research UK. All rights reserved 0007-0920/13 
Lung cancer is the second leading cause of cancer mortality in women worldwide. In the past decades, lung cancer incidence rates have decreased or leveled off among men, whereas they are increasing among women, reflecting differences in pattern of smoking habits, with women starting smoking several decades later than males. Tobacco smoking is the major cause of lung cancer, accounting for $80 \%$ of the worldwide lung cancer burden in males and $50 \%$ in females (Jemal et al, 2011). There is increasing evidence that women present different clinical patterns of lung cancer from men: they are more likely to develop adenocarcinoma, tend to be younger than men and experience better survival rates (Kiyohara and Ohno, 2010; Donington and Colson, 2011). These gender differences raised the question of the possible role of female hormones in lung cancer carcinogenesis and found support by studies that have identified steroid receptors in lung cancer cell lines and tumour tissue (Chen et al, 2008). However, the significance of oestrogens and progesterone receptor expression in lung cells is still unknown as these receptors are expressed in many other organs (Greiser et al, 2010). Oestrogens could also interact with cigarette smoking by accelerating the metabolism of smoking-derived carcinogens (Meireles et al, 2010; Siegfried, 2010). Despite the growing number of studies evaluating the biological plausibility of hormonal factors in lung cancer carcinogenesis, the mechanisms through which they could contribute to lung cancer risk are still not fully clarified and are likely to be more complex than originally thought. Oestrogens directly promote cellular proliferation in the lung and can induce direct DNA damage (supporting a role in lung cancer development). However, they can also increase apoptosis, reduce cell proliferation through oestrogen receptor- $\beta$-mediated mechanisms and stimulate the immune system (thus playing a protective role). Progesterone seems to act as a growth-inhibiting factor on malignant lung cells. In addition, the crosstalk between different pathways involved in oestrogen response, such as interactions with epidermal growth factor or insulin-like growth factor, enhances the complexity of the regulatory mechanisms promoting tumour growth.

The evidence deriving from epidemiological studies is conflicting too. The first clue of a possible role of hormone replacement therapy (HRT) in lung cancer risk was from a small case-control study (Taioli and Wynder, 1994) that showed an increased risk in women ever using HRT. Numerous subsequent studies gave mixed results (Blackman et al, 2002; Kreuzer et al, 2003; Schabath et al, 2004; Liu et al, 2005; Elliott and Hannaford, 2006; Chen et al, 2007; Kabat et al, 2007; Ramnath et al, 2007; Schwartz et al, 2007; Rodriguez et al, 2008; Weiss et al, 2008; Chlebowski, 2009; Seow et al, 2009; Baik et al, 2010; Chlebowski et al, 2010; Slatore et al, 2010; Brinton et al, 2011; Clague et al, 2011; Meinhold et al, 2011). Most case-control studies (excluding those included in the present analysis) observed a reduced risk (Blackman et al, 2002; Kreuzer et al, 2003; Schabath et al, 2004; Elliott and Hannaford, 2006; Chen et al, 2007; Ramnath et al, 2007), whereas cohort studies failed to show a clear association between HRT and lung cancer risk. Three cohort studies were conducted among nonsmoking women in China (Weiss et al, 2008; Seow et al, 2009) and Japan (Liu et al, 2005), thus avoiding the possible residual confounding by smoking, but the number of cases who ever used HRT was too small (4, 12 and 24, respectively) to allow interpretation of the findings. Two case-control studies (Blackman et al, 2002; Schabath et al, 2004) and four cohort studies (Rodriguez et al, 2008; Baik et al, 2010; Slatore et al, 2010; Clague et al, 2011) were able to examine the risk by HRT type (oestrogen only and oestrogen plus progestin). The use of oestrogen only was not associated with an increased lung cancer risk consistently across studies; only in the VITAL study (Slatore et al, 2010), women using combined (oestrogen + progestin) hormone therapy for $>10$ years showed an $\sim 50 \%$ increased risk.

Two randomised clinical trial evaluated HRT type and lung cancer risk. The Heart and Estrogen/Progestin Replacement Study
(HERS) (Hulley et al, 1998), a randomised trial of oestrogen plus progestin therapy in postmenopausal women with coronary diseases at enrollment, is limited by the modest number of lung cancer cases observed, the short duration of follow-up and the old age of study participants. In the Women Health Initiative randomised controlled trial, the use of oestrogen alone was not associated with increased lung cancer incidence or mortality (Chlebowski et al, 2010), whereas oestrogen plus progestin therapy was associated with an increased lung cancer mortality but not incidence (Chlebowski, 2009). However, the limited number of observed cases precluded firm conclusions.

Most of the scientific literature on oral contraceptive use (OC) points to no association with lung cancer risk (Taioli and Wynder, 1994; Elliott and Hannaford, 2006; Kabat et al, 2007; Schwartz et al, 2007; Weiss et al, 2008; Seow et al, 2009; Hannaford et al, 2010; Vessey et al, 2010; Meinhold et al, 2011), with two possible exceptions showing, however, opposite results: a reduced lung cancer risk among ever OC users in a case-control study (Kreuzer et al, 2003) and a slightly increased risk among women using OC for $>5$ years in a cohort study (Baik et al, 2010).

To shed light on the role of hormonal factors in lung cancer aetiology, we evaluated the association between hormone use (OC and HRT) and lung cancer risk in women, by performing a pooled analysis of data from six case-control studies from the International Lung Cancer Consortium (ILCCO). The large sample size allowed to examine the risk by type of HRT, smoking status and histology.

\section{MATERIALS AND METHODS}

Study population. The International Lung Cancer Consortium (http://ilcco.iarc.fr) was established in 2004 with the aim of sharing comparable data from ongoing lung cancer case-control and cohort studies. The individual-level data across studies have been pooled. Data were checked for inconsistency, inadmissible values, aberrant distributions and outliers before being standardised into a common data set. To be included in the present pooled analysis, studies had to have data on reproductive and hormonal factors in women. Seven case-control studies were eligible. One of them (MSKCC), however, had both cases and controls represented by lung cancer patients (multiple and single non-small-cell lung cancers, respectively) and it was excluded. Finally, the analysis included a total of six studies, with 1961 cases and 2609 controls overall (Table 1). Three studies were conducted in the United States (MLCS, NELCS and WELD), two in Europe (EAGLE and ESTHER) and one in Canada (TORONTO). Most studies recruited population controls only, whereas two studies recruited also hospital controls (319 and 353 in the MLCS and TORONTO study, respectively). Controls were frequency matched to cases on age in all studies but the TORONTO study, some were also matched on ethnicity, one on residential area and in the MLCS study an additional matching variable for hospital controls was smoking status.

The pooled data set included the following clinical and sociodemographic data: case status (case or control), age at diagnosis (cases) and at interview (cases and controls), ethnicity, education, body mass index (BMI), lifetime cigarette smoking history and lung cancer histology (coded according to the International Classification of Diseases for Oncology, Third Edition; Fritz et al, 2000). Institutional approval and written informed consent from participants had been collected at each study site.

Reproductive and hormonal factors. Reproductive variables of interest were: menopause status (postmenopausal defined as 'no menstrual periods for at least 1 year' before the time of diagnosis or interview), menopause reason (natural $v s$ induced: surgery/ 
Table 1. Characteristics of the included studies

\begin{tabular}{|c|c|c|c|c|c|c|}
\hline $\begin{array}{l}\text { Study name } \\
\text { Principal investigator }\end{array}$ & Country & Enrolment period & Matching variables & Cases & $\begin{array}{l}\text { Controls } \\
\text { Source }\end{array}$ & Total \\
\hline $\begin{array}{l}\text { EAGLE } \\
\text { MT Landi (Pesatori et al, 2013) }\end{array}$ & Italy & $2002-2005$ & Age, residential area & 407 & $\begin{array}{c}499 \\
\text { Population }\end{array}$ & 906 \\
\hline $\begin{array}{l}\text { ESTHER } \\
\text { H Brenner }\end{array}$ & Germany & $2000-2003$ & Age & 52 & $\begin{array}{c}52 \\
\text { Population }\end{array}$ & 104 \\
\hline $\begin{array}{l}\text { MLCS } \\
\text { CC Harris (Meinhold et al, 2011) }\end{array}$ & USA & $1998-2010$ & Age, ethnicity, pack-years, hospital & 540 & $\begin{array}{c}777 \\
\text { Population }+ \text { hospital }\end{array}$ & 1317 \\
\hline $\begin{array}{l}\text { NELCS } \\
\text { EJ Duell (Heck et al, 2009) }\end{array}$ & USA & $2005-2008$ & Age & 150 & $\begin{array}{c}148 \\
\text { Population }\end{array}$ & 298 \\
\hline $\begin{array}{l}\text { TORONTO } \\
\text { JR McLaughlin (Brenner et al, 2010) }\end{array}$ & Canada & 1997-2002 & Ethnicity & 235 & $\begin{array}{c}558 \\
\text { Population }+ \text { hospital }\end{array}$ & 793 \\
\hline $\begin{array}{l}\text { WELD } \\
\text { AG Schwartz (Schwartz et al, 2007) }\end{array}$ & USA & $2002-2007$ & Age, ethnicity & 577 & $\begin{array}{c}575 \\
\text { Population }\end{array}$ & 1152 \\
\hline Total & & & & 1961 & 2609 & 4570 \\
\hline
\end{tabular}

chemotherapy or radiation therapy/other) and menopause age. Information on ovariectomy (defined as bilateral ovary removal) and hysterectomy was collected in four (EAGLE, ESTHER, MLCS and TORONTO) and three (ESTHER, MLCS and TORONTO) studies, respectively.

Main exposures of interest were OC use and HRT. We defined OCs as 'pills for birth control', and HRT as 'any use of hormones (pills or patches) just before, during or after menopause' (as suggested by Meinhold et al, 2011), with 'just before' delimited to 1 year before menopause.

The durations of OC/HRT were defined as the difference between OC/HRT quitting and starting ages (or between age at diagnosis and starting age if quitting age fell beyond age at diagnosis), or the declared years of total consumption. When the information was available (MLCS, TORONTO and WELD), periods (years or months) of suspension from hormone use were considered in calculating therapy duration.

Three studies (MLCS, TORONTO and WELD) provided information on HRT type as well. We categorised HRT type as: 'Oestrogen (E) Only' or 'Progesterone (P) Only' if a woman used only oestrogens or only progesterone as HRT in her entire life; 'E $+\mathrm{P}$ Only' if a woman used combined oestrogens and progesterone as HRT in her entire life; and ' $\mathrm{E}+\mathrm{P}$ Mixed' if a woman used unopposed oestrogens, progesterone or combined HRT in different moments of her life. The HRT type-specific durations were calculated for the ' $\mathrm{E}$ Only' and ' $\mathrm{E}+\mathrm{P}$ Only' categories (the most represented ones), following the same criteria as previously defined.

Statistical analysis. Potential differences between cases and controls were evaluated with the Mann-Whitney $U$-test for ordinal and continuous variables and the Pearson's $\chi^{2}$ test for categorical variables, after excluding subjects without available information. We excluded 43 subjects because of missing information on smoking, reproductive and hormonal variables (41 cases and 2 controls).

To model information on smoking habits, we first used a common variable on smoking status (never/former/current) from the pooling data set. Never smokers were individuals who reported smoking $<100$ cigarettes in their lifetime. Former smokers reported smoking cessation at least 2 years before interview. We then represented most of the relevant aspects of smoking history (duration, time as cessation and cigarettes/day) by a single aggregate measure, the Comprehensive Smoking Index (CSI), as originally proposed by Hoffmann et al (2001), and subsequently modified by Leffondré et al (2006).
To investigate potential associations between lung cancer and the independent variables of interest, we performed unconditional logistic regression models, adjusted for age $(<55$; 55-62; 63-69; and $\geqslant 70$ years) at diagnosis or interview (for cases and controls respectively), ethnicity (Caucasian/non-Caucasian), smoking status (ever/never), CSI (continuous), BMI (continuous), education (low, medium, high) and study (categorical). Further adjustment for age at menopause, number of livebirths and environmental tobacco smoke (at home during childhood or adulthood and at work) did not change the results.

For categorical exposure variables with more than two levels, we performed tests for trend (both including and excluding 'nonexposed subjects' as reference category) by assigning a unit score to each category.

To evaluate interaction on a multiplicative scale between the main variables of interest (OC, HRT and HRT type) and smoking or BMI, we ran logistic regression models stratifying by smoking status (never/former/current) and BMI (underweight/normal weight/overweight/obese), and compared the log-likelihood of models with and without product terms. In three studies, BMI clearly referred to at least 1 year before diagnosis or interview, whereas current BMI was collected in the remaining studies. As findings did not differ between the two groups, we considered $\mathrm{BMI}$ as a unique variable independently from the collection time (data not shown). For smoking, we also evaluated interaction on an additive scale, calculating the 'Relative Excess Risk due to Interaction' (RERI) (Andersson et al, 2005). The lowest risk category of OC/HRT use in never smokers was used as reference (Rothman, 2002).

Meta-analyses of study-specific odds ratios (ORs) and 95\% confidence intervals (95\% CIs) were performed as well. Test for homogeneity based on Cochran's Q (Cochran, 1954) and $I^{2}$ (Higgins et al, 2003) statistics were calculated. If no substantial heterogeneity was detected, we ran a fixed effect meta-analysis using inverse-variance weighting (Egger et al, 2001) to calculate summary estimates. When there was evidence of some heterogeneity, we conducted an influence analysis, evaluating the impact of each single study on the metaanalytic estimate. As a sensitivity analysis, we re-ran the fixed effect meta-analysis after excluding the study contributing the most to the heterogeneity.

Finally, we performed multinomial logistic regression models to test the homogeneity (using Wald test) of the association between the main hormonal variables (OC/HRT) and lung cancer risk across main histologic types (adenocarcinoma, squamous cell carcinoma and small cell carcinoma). 
All tests were two sided. Statistical analyses were performed using Stata 12 (Stata Corp 2011, College Station, TX, USA).

\section{RESULTS}

Table 2 reports the demographic and hormonal factor distributions for cases and controls. The majority of the population was Caucasian, cases had lower education, a greater proportion of normal or underweight women and, as expected, a higher proportion of smokers. Adenocarcinoma was the predominant histologic subtype of lung cancer followed by squamous cell carcinoma. With regard to reproductive and hormonal factors, cases included a higher proportion of women who were postmenopausal. Data on bilateral ovariectomy were collected in four studies (1234 cases, 63\%, and 1886 controls, 72\%). Information on hysterectomy was available in three studies (827 cases, $42 \%$, and 1387 controls, 53\%).

The proportion of women who ever used OC did not differ between cases and controls, whereas HRT was more frequent among controls. In the subgroup of women for whom data on HRT type were available, approximately half of the study population used oestrogen only therapy, whereas $24.9 \%$ of cases and $29.4 \%$ of controls had combined HRT (E + P Only).

Table 3 shows the pooled ORs (adjusted for age at interview, ethnicity, smoking status, CSI, BMI, education and study) for each exposure variable. We found a reduced risk of lung cancer for women who ever used OC and no evidence of a dose-response relationship associated with the duration of OC use among users ( $P$-trend excluding never users as reference category $=0.2$ ). The same held for HRT, with a decreased lung cancer risk among ever users and no trend with treatment duration. Similar results emerged when analysing HRT type: both the use of oestrogen only and combined HRT were associated with decreased risks $(\mathrm{OR}=0.76$; 95\% CI: $0.61-0.94$ and $\mathrm{OR}=0.66$; 95\% CI: $0.49-0.88$, respectively), without a clear dose-response relationship with years of use. The exclusion of hospital controls did not change the results (data not shown).

Women having ever used both OC and HRT showed the greatest reduction in risk when compared with never users $(\mathrm{OR}=0.61 ; 95 \%$ CI: $0.47-0.78)$.

Study-specific ORs and meta-analytic estimates for OC use, HRT and HRT type are shown in Figure 1. The inverse-variance fixed-effect ORs for each variable examined were quite similar to those obtained with the logistic regression model. No heterogeneity across studies was detected for OC $\left(I^{2}=0.0 \%\right)$, whereas HRT study-specific estimates showed a low heterogeneity $\left(I^{2}=35.9 \%\right)$. The influence analysis to detect the study-specific contribution to the meta-analytic estimate of HRT showed the NELCS study as contributing the most to the interstudy variability (Supplementary Figure 1). We thus re-ran the meta-analysis after excluding NELCS, and found no heterogeneity $\left(I^{2}=0.0 \%\right)$ with a slightly lower OR $(0.74$; 95\% CI: $0.63-0.88)$.

We examined the results for OC, HRT and HRT type (Table 4) by smoking status (never/former/current). The point estimates associated with all three variables were generally reduced across the smoking strata. For OC the greatest risk reduction was seen in former smokers; HRT showed a statistically significant decreased risk among never smokers. Looking at HRT type, the use of oestrogen only showed the lowest reduced risk among former smokers, whereas the combined HRT was associated with the greatest reduction in risk among never smokers.

No interaction between hormonal factors and smoking status was detected on both multiplicative $(\mathrm{OC} P$ for interaction $=0.4$; HRT $P$ for interaction $=0.3$; oestrogen only $P$ for interaction $=0.6$; $\mathrm{E}+\mathrm{P}$ only $P$ for interaction $=0.2)$ and additive scale
(Supplementary Table 1: the lower CIs of all calculated RERIs fell below zero).

The association between hormone use and lung cancer risk did not change across BMI categories (Supplementary Table 2).

When assessed by histologic subtypes (Table 5), the greatest reduction in risk associated with the ever use of $\mathrm{OC}$ was seen for squamous cell carcinoma ( $\mathrm{OR}=0.53$; 95\% CI: $0.37-0.76)$, whereas HRT was associated with a significant reduction in lung cancer risk in both adenocarcinoma and small cell carcinoma $(\mathrm{OR}=0.79 ; 95 \%$ CI: $0.66-0.95$ and $\mathrm{OR}=0.37$; 95\% CI: $0.19-0.71$, respectively). When stratifying by smoking status across histologic subtypes (Supplementary Table 3) the findings, although hampered by small numbers in some cells, basically confirmed what was observed in the entire study population (Table 5).

The analysis on HRT type in women with adenocarcinoma confirmed what was observed in the whole population: $\mathrm{OR}=0.76$ (95\% CI: $0.59-0.98)$ for oestrogen only and OR $=0.59$ (95\% CI: 0.41-0.83) for combined E + P. Similarly, no relevant differences were observed in the stratum-specific estimates of smoking status categories.

\section{DISCUSSION}

Our study is one of the largest investigations conducted to date to evaluate the association between HRT and OC use with lung cancer risk in women. Only one cohort study (Brinton et al, 2011) included a larger number of cases but did not collect information on HRT type.

Overall, we found a reduced lung cancer risk for both OC use and HRT. The reduction in lung cancer risk appeared only marginally, if not at all, influenced by the duration of OC use or HRT. The greatest reduction in risk was seen among women using both OC and HRT during their whole life. The inverse association between HRT and lung cancer was found in both women who ever used $\mathrm{E}$ only and women who ever used $\mathrm{E}+\mathrm{P}$ formulation. The associations were not modified by BMI. When we stratified by smoking status, there was no evidence of interaction on both multiplicative and additive scales between hormone use and smoking. However, the risk reduction was somehow attenuated among smokers. It is well recognised that smoking can interact with oestrogen metabolism through the induction of phase-I enzymes (e.g., CYP1A1 and CYP1B1), leading to both the activation of cigarette smoke carcinogens and the production of highly reactive catechols that form DNA adducts and activate ER (Meireles et al, 2010; Siegfried, 2010). Smoking is associated with a lower total body fat mass and therefore reduces the major source of oestrogens in postmenopausal women (i.e., the adipose tissue, where androgens are converted to oestrogens) (Tanko and Christiansen, 2004). All these mechanisms might be invoked as a possible explanation of the attenuation of the observed risk reduction among smokers.

The protective effect of OC use was more evident for squamous cell histology, whereas the greatest reduction in risk for HRT was found for small cell carcinoma; however, the small number of cases in these histology subtypes prevents any firm conclusion.

Our findings suggest that exogenous hormones may have a protective effect in lung cancer development consistently with a meta-analysis of previously published case-control studies showing a reduced lung cancer risk in HRT ever users (OR 0.81; 95\% CI 0.68-0.97) (Oh et al, 2010).

The evidence emerging form cohort studies is murkier. Three cohort studies in Asian non-smoking women lacked statistical power (Liu et al, 2005; Weiss et al, 2008; Seow et al, 2009). The findings in the Cancer Prevention Study II Nutrition Cohort support our results (Rodriguez et al, 2008), whereas other cohort 
Table 2. Demographic, reproductive and hormonal characteristics of the study population among cases and controls

\begin{tabular}{|l|l|l|}
\hline Characteristic Controls & Cases
\end{tabular}

\begin{tabular}{|c|c|c|c|c|}
\hline \multicolumn{5}{|c|}{ Age at interview (years) } \\
\hline $\begin{array}{l}<55 \\
55-62 \\
63-69 \\
\geqslant 70\end{array}$ & $\begin{array}{l}436 \\
457 \\
495 \\
573\end{array}$ & $\begin{array}{l}(22.2) \\
(23.3) \\
(25.2) \\
(29.2)\end{array}$ & $\begin{array}{l}733 \\
609 \\
636 \\
631\end{array}$ & $\begin{array}{l}(28.1) \\
(23.3) \\
(24.4) \\
(24.2)\end{array}$ \\
\hline
\end{tabular}

\section{Ethnicity}

Caucasian

Non-Caucasian

African-American

\begin{tabular}{c|c}
1590 & $(81.1)$ \\
367 & $(18.7)$ \\
135 & $(6.9)$ \\
161 & $(8.2)$ \\
45 & $(2.3)$ \\
26 & $(1.3)$ \\
4 & $(0.2)$
\end{tabular}

\begin{tabular}{l|l}
2057 & $(78.8)$
\end{tabular}

Mexican

Asian

Mixed $^{\mathrm{a}}$

Missing

(0.2)

(21.1)

(5.1)

(11.7)

(2.3)

(2.0)

(0.1)

\section{Education (years of attendance)}

Low (1-9)

Medium (10-15)

High $(\geqslant 16)$

Missing

\begin{tabular}{c|c}
362 & $(18.5)$ \\
969 & $(49.4)$ \\
608 & $(31.0$ \\
22 & $(1.1)$
\end{tabular}

Missing

\section{Smoking status}

Never

Former

Current

Missing

Comprehensive smoking

index (CSI)

344

671
935

$(47.7)$

11

(0.6)

\begin{tabular}{l|l}
1251 & $(48.0$
\end{tabular}

665

$P<0.001$

1.35

(0.59-1.74)

$P<0.001$

35

(0-0.93)

\section{BMI $\left(\mathrm{kg} \mathrm{m}^{-2}\right)$}

Underweight ( $<18.5)$

Normal (18.5-24.9)

Overweight (25.0-29.9)

Obese $(\geqslant 30.0)$

Missing

0.02
$P<0.001$

\begin{tabular}{c|c}
111 & $(5.7)$ \\
887 & $(45.2)$ \\
587 & $(29.9)$ \\
349 & $(17.8)$ \\
27 & $(1.4)$
\end{tabular}

53

53
1049

762

27

31

(2.0)

(40.2)

(29.2)

(27.4)

(1.2)

\section{Histology}

SCLC

NSCLC

Squamous cell

Large cell

Adenocarcinoma

Non-small-cell carcinoma/

NOS

Carcinoma/NOS

Carcinoid

Other/missing/info NA

84
1643
266
67
1074
236

52
4
178

$P<0.001$

\begin{tabular}{l}
$0)$ \\
$.5)$ \\
\hline 3$)$
\end{tabular}

$P<0.001$

(20)

\section{Menopause status}

\begin{tabular}{|c|c|c|c|c|}
\hline $\begin{array}{l}\text { Premenopausal } \\
\text { Postmenopausal } \\
\text { Missing }\end{array}$ & $\begin{array}{c}156 \\
1792 \\
13\end{array}$ & $\begin{array}{c}(8.0) \\
(91.4) \\
(0.7)\end{array}$ & $\begin{array}{c}508 \\
2093 \\
8\end{array}$ & $\begin{array}{c}(19.5) \\
(80.2) \\
(0.3)\end{array}$ \\
\hline & \multicolumn{4}{|c|}{$P<0.001$} \\
\hline \multicolumn{5}{|c|}{ Number of livebirths } \\
\hline $\begin{array}{l}\text { Nulliparous } \\
1 \\
2 \\
3+ \\
\text { Missing }\end{array}$ & $\begin{array}{c}270 \\
341 \\
582 \\
766 \\
2\end{array}$ & $\begin{array}{c}(13.8) \\
(17.4) \\
(29.7) \\
(39.1) \\
(0.1)\end{array}$ & $\begin{array}{c}439 \\
415 \\
815 \\
926 \\
14\end{array}$ & $\begin{array}{c}(16.8) \\
(15.9) \\
(31.2) \\
(35.5) \\
(0.5)\end{array}$ \\
\hline
\end{tabular}




\section{Table 2. (Continued)}

\begin{tabular}{|c|c|c|c|c|}
\hline Characteristic & \multicolumn{2}{|c|}{ Cases } & \multicolumn{2}{|c|}{ Controls } \\
\hline & \multicolumn{4}{|c|}{$P<0.001$} \\
\hline \multicolumn{5}{|l|}{ Menopause reason } \\
\hline $\begin{array}{l}\text { Natural } \\
\text { Induced } \\
\text { Surgery } \\
\text { Chemo-/radiotherapy } \\
\text { Other } \\
\text { Missing }\end{array}$ & $\begin{array}{c}1080 \\
703 \\
558 \\
86 \\
59 \\
9\end{array}$ & $\begin{array}{l}(60.3) \\
(39.2) \\
(31.1) \\
(4.8) \\
(3.3) \\
(0.5)\end{array}$ & $\begin{array}{c}1307 \\
779 \\
679 \\
51 \\
49 \\
7\end{array}$ & $\begin{array}{l}(62.5) \\
(37.2) \\
(32.4) \\
(2.4) \\
(2.4) \\
(0.3)\end{array}$ \\
\hline & \multicolumn{4}{|c|}{$P=0.2$} \\
\hline \multirow[t]{2}{*}{ Menopause age (years) } & 47 & $(40-50)$ & 48 & $(42-52)$ \\
\hline & \multicolumn{4}{|c|}{$P<0.001$} \\
\hline \multirow[t]{2}{*}{ Natural } & 49 & $(46-52)$ & 50 & $(48-53)$ \\
\hline & \multicolumn{4}{|c|}{$P<0.001$} \\
\hline \multirow[t]{2}{*}{ Induced } & 40 & $(34-46)$ & 41 & $(36-47)$ \\
\hline & \multicolumn{4}{|c|}{$P=0.01$} \\
\hline \multicolumn{5}{|l|}{ Ovariectomy $^{b}$} \\
\hline $\begin{array}{l}\text { No } \\
\text { Yes } \\
\text { Missing }\end{array}$ & $\begin{array}{c}1027 \\
204 \\
3\end{array}$ & $\begin{array}{c}(83.2) \\
(16.5) \\
(0.3)\end{array}$ & $\begin{array}{c}1615 \\
271 \\
0\end{array}$ & $\begin{array}{c}(85.6) \\
(14.4) \\
-\end{array}$ \\
\hline Missing & \multicolumn{4}{|c|}{$P=0.09$} \\
\hline
\end{tabular}

\section{Hysterectomy ${ }^{\mathrm{c}}$}

\begin{tabular}{|c|c|c|c|c|}
\hline $\begin{array}{l}\text { No hysterectomy/no } \\
\text { ovariectomy }\end{array}$ & 530 & $(64.1)$ & 966 & $(69.7$ \\
\hline No hysterectomy/ovariectomy & 18 & $(2.2)$ & 20 & (1.4) \\
\hline $\begin{array}{l}\text { No hysterectomy/ovariectomy } \\
\text { unknown }\end{array}$ & 1 & $(0.1)$ & 0 & - \\
\hline Hysterectomy/no ovariectomy & 127 & $(15.4)$ & 197 & $(14.2$ \\
\hline Hysterectomy/ovariectomy & 142 & $(17.2)$ & 194 & $(14.0$ \\
\hline $\begin{array}{l}\text { Hysterectomy/ovariectomy } \\
\text { unknown }\end{array}$ & 9 & (1.1) & 10 & $(0.7)$ \\
\hline
\end{tabular}

\section{Oral contraceptives (OC)}

\begin{tabular}{|c|c|c|c|c|}
\hline $\begin{array}{l}\text { Never } \\
\text { Ever } \\
\text { Missing }\end{array}$ & $\begin{array}{l}818 \\
958 \\
185\end{array}$ & $\begin{array}{c}(41.7) \\
(48.9) \\
(9.4)\end{array}$ & $\begin{array}{c}1020 \\
1322 \\
267\end{array}$ & $\begin{array}{l}(39.1) \\
(50.7) \\
(10.2)\end{array}$ \\
\hline & \multicolumn{4}{|c|}{$P=0.1$} \\
\hline OC duration (years) & 4 & $(1-9)$ & 4.9 & $(1.5-9.8)$ \\
\hline
\end{tabular}

\section{Hormone replacement therapy (HRT) ${ }^{d}$}

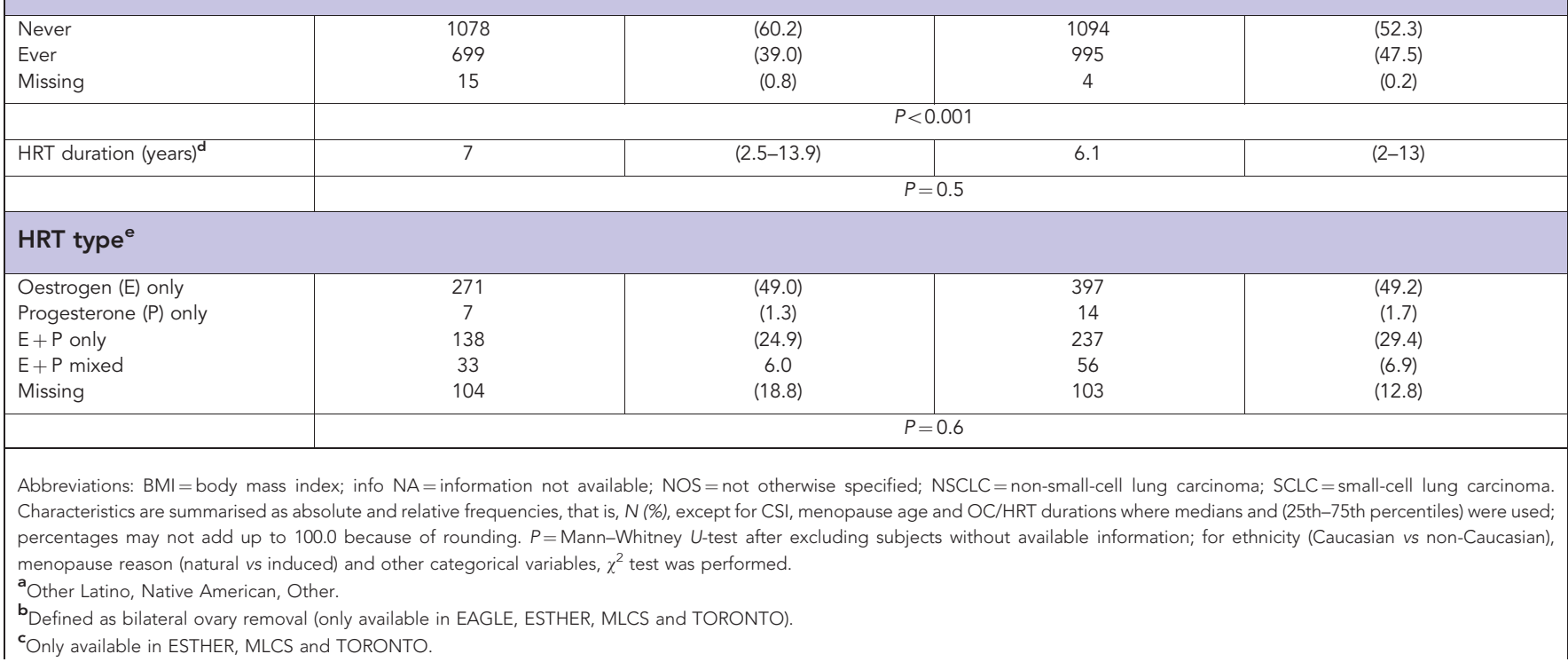


Table 3. Association between main hormonal factors and lung cancer risk

\begin{tabular}{|c|c|c|c|c|c|}
\hline Hormonal factor & Cases & Controls & OR & $95 \% \mathrm{Cl}$ & $p^{a}$ \\
\hline \multicolumn{6}{|l|}{ OC } \\
\hline $\begin{array}{l}\text { Never } \\
\text { Ever } \\
\text { Missing }\end{array}$ & $\begin{array}{l}818 \\
958 \\
185 \\
\end{array}$ & $\begin{array}{c}1020 \\
1322 \\
267\end{array}$ & $\begin{array}{c}1 \\
0.81\end{array}$ & $(0.68-0.97)$ & 0.02 \\
\hline \multicolumn{6}{|l|}{ OC duration } \\
\hline $\begin{array}{l}\text { Never users } \\
\leqslant 1 \text { year } \\
1-5 \text { years } \\
5-10 \text { years } \\
>10 \text { years } \\
\text { Missing }\end{array}$ & $\begin{array}{l}818 \\
262 \\
287 \\
230 \\
156 \\
208\end{array}$ & $\begin{array}{l}1020 \\
316 \\
421 \\
330 \\
238 \\
284\end{array}$ & $\begin{array}{c}1 \\
0.85 \\
0.81 \\
0.78 \\
0.70\end{array}$ & $\begin{array}{l}(0.67-1.09) \\
(0.65-1.03) \\
(0.61-1.00) \\
(0.53-0.93)\end{array}$ & 0.007 \\
\hline \multicolumn{6}{|l|}{$H R T^{c}$} \\
\hline $\begin{array}{l}\text { Never } \\
\text { Ever } \\
\text { Missing }\end{array}$ & $\begin{array}{c}1078 \\
699 \\
15\end{array}$ & $\begin{array}{c}1094 \\
995 \\
4\end{array}$ & $\begin{array}{c}1 \\
0.77\end{array}$ & $(0.66-0.90)$ & 0.001 \\
\hline \multicolumn{6}{|l|}{ HRT duration ${ }^{c}$} \\
\hline $\begin{array}{l}\text { Never users } \\
\leqslant 2 \text { years } \\
2-7 \text { years } \\
7-14 \text { years } \\
>14 \text { years } \\
\text { Missing }\end{array}$ & $\begin{array}{c}1078 \\
157 \\
166 \\
156 \\
142 \\
93\end{array}$ & $\begin{array}{c}1094 \\
257 \\
227 \\
220 \\
209 \\
86\end{array}$ & $\begin{array}{c}1 \\
0.61 \\
0.84 \\
0.79 \\
0.70\end{array}$ & $\begin{array}{l}(0.47-0.78) \\
(0.65-1.09) \\
(0.60-1.03) \\
(0.53-0.92)\end{array}$ & $\begin{array}{c} \\
0.004 \\
0.7^{\mathrm{b}}\end{array}$ \\
\hline \multicolumn{6}{|l|}{ HRT type ${ }^{d}$} \\
\hline $\begin{array}{l}\text { Never users } \\
\text { Oetrogen Only } \\
\mathrm{E}+\mathrm{P} \text { only } \\
\text { Missing }\end{array}$ & $\begin{array}{l}676 \\
271 \\
138 \\
120\end{array}$ & $\begin{array}{l}685 \\
397 \\
237 \\
119\end{array}$ & $\begin{array}{c}1 \\
0.76 \\
0.66\end{array}$ & $\begin{array}{l}(0.61-0.94) \\
(0.49-0.88)\end{array}$ & $\begin{array}{c}0.01 \\
0.005\end{array}$ \\
\hline \multicolumn{6}{|c|}{ HRT type-specific duration ${ }^{d}$} \\
\hline \multicolumn{6}{|l|}{ Oestrogen only } \\
\hline $\begin{array}{l}\text { Never users } \\
\leqslant 2 \text { years } \\
2-8 \text { years } \\
8-16 \text { years } \\
>16 \text { years }\end{array}$ & $\begin{array}{l}676 \\
67 \\
66 \\
61 \\
70\end{array}$ & $\begin{array}{c}685 \\
101 \\
92 \\
91 \\
105\end{array}$ & $\begin{array}{c}1 \\
0.67 \\
0.81 \\
0.80 \\
0.71\end{array}$ & $\begin{array}{l}(0.47-0.98) \\
(0.56-1.19) \\
(0.54-1.18) \\
(0.49-1.02)\end{array}$ & $\begin{array}{l}0.03 \\
0.9^{b}\end{array}$ \\
\hline \multicolumn{6}{|l|}{$\mathrm{E}+\mathrm{P}$ only } \\
\hline $\begin{array}{l}\text { Never users } \\
\leqslant 2 \text { years } \\
2-5 \text { years } \\
5-10 \text { years } \\
>10 \text { years }\end{array}$ & $\begin{array}{l}676 \\
30 \\
35 \\
32 \\
39\end{array}$ & $\begin{array}{c}685 \\
60 \\
60 \\
67 \\
47\end{array}$ & $\begin{array}{c}1 \\
0.55 \\
0.69 \\
0.52 \\
0.94\end{array}$ & $\begin{array}{l}(0.33-0.93) \\
(0.41-1.16) \\
(0.31-0.87) \\
(0.56-1.57)\end{array}$ & $\begin{array}{l}0.04 \\
0.5^{b}\end{array}$ \\
\hline \multicolumn{6}{|l|}{ OC/HRT combined ${ }^{c}$} \\
\hline $\begin{array}{l}\text { OC never/HRT never } \\
\text { OC ever/HRT never } \\
\text { OC never/HRT ever } \\
\text { OC ever/HRT ever } \\
\text { Missing }\end{array}$ & $\begin{array}{l}539 \\
426 \\
224 \\
417 \\
186 \\
\end{array}$ & $\begin{array}{l}552 \\
390 \\
327 \\
566 \\
258 \\
\end{array}$ & $\begin{array}{c}1 \\
0.80 \\
0.74 \\
0.61\end{array}$ & $\begin{array}{l}(0.62-1.03) \\
(0.57-0.96) \\
(0.47-0.78)\end{array}$ & $\begin{array}{c}0.09 \\
0.02 \\
<0.001\end{array}$ \\
\hline \multicolumn{6}{|c|}{ 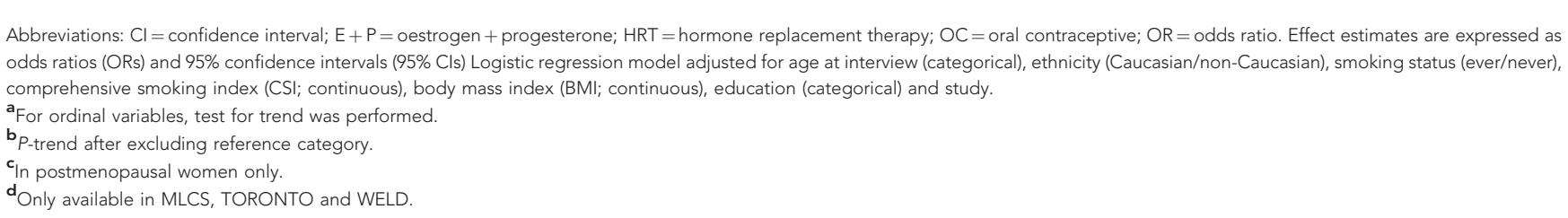 } \\
\hline
\end{tabular}


A

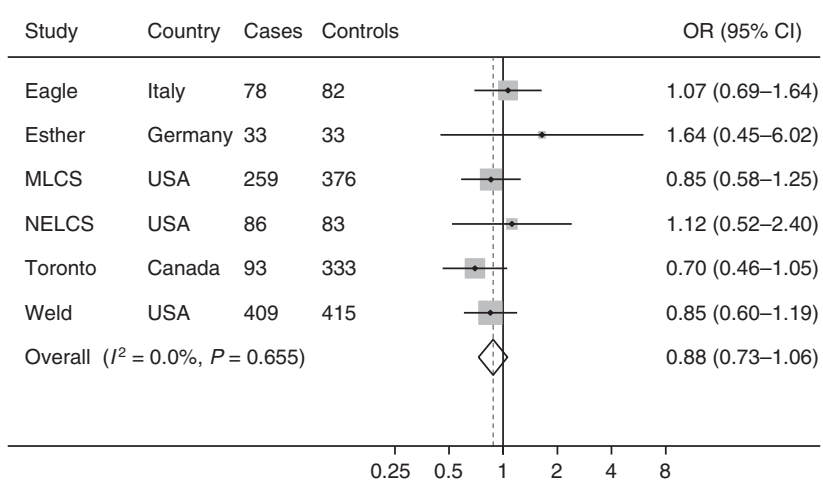

B

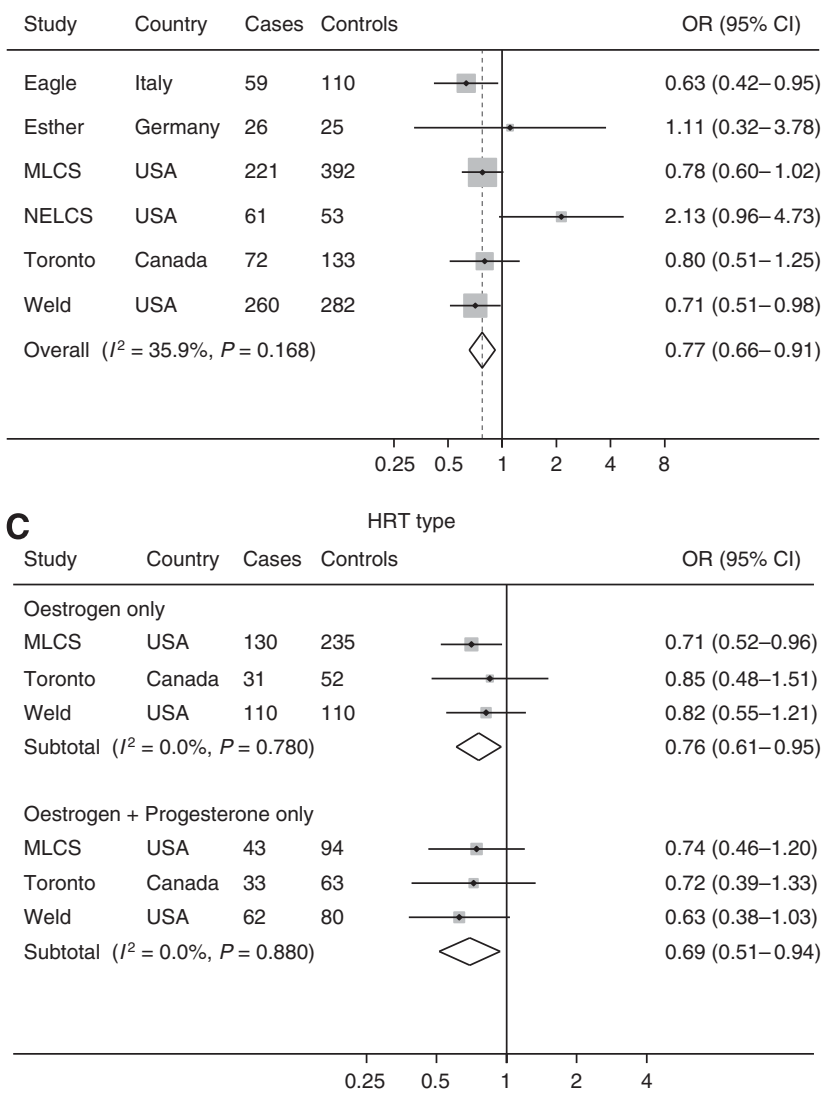

Figure 1. Study-specific odds ratios and meta-analytic estimates for oral contraceptive use (A), hormone replacement therapy (B) and HRT Type (C). Inverse-variance fixed-effect ORs adjusted for age at interview, ethnicity, smoking status, CSI, BMI and education. The number of cases and controls refers to OC/HRT/HRT Type ever users.

studies (Kabat et al, 2007; Slatore et al, 2010; Brinton et al, 2011; Clague et al, 2011) showed no association between HRT and lung cancer risk.

Considering HRT type, oestrogen only was not associated with an increased lung cancer risk in either observational studies (Blackman et al, 2002; Rodriguez et al, 2008; Baik et al, 2010; Slatore et al, 2010; Clague et al, 2011) or a randomised clinical trial (Chlebowski et al, 2010), whereas the use of combined oestrogen + progestin HRT was associated with an increased risk in two studies: long-term users ( $>10$ years) showed a modest augmented risk in the VITAL study (Slatore et al, 2010), whereas the Women Health Initiative randomised trial (Chlebowski, 2009) reported an association with increased lung cancer mortality but not incidence (although based on a small number of deaths).

Inconsistent findings between studies might depend on study design (case-control vs cohort studies). Case-control studies are possibly more prone to selection and sometimes to recall bias. On the other hand, cohort studies may be affected by low respondent rates at enrollment and poorer information on hormone use history (Slatore et al, 2010; Brinton et al, 2011).

Our study has several strengths: we could rely on a large sample size that allowed us to investigate duration of OC and HRT over a long period of time; we were also able to analyse HRT type and to control for major confounders. All the studies included in our analysis enrolled incident lung cancer cases from well-defined source populations. One study (WELD) excluded women with a previous history of breast cancer because of the association between reproductive factors and this tumour. The number of subjects with previous breast cancer diagnosis was only 76 (30 cases and 46 controls). Analyses excluding these subjects yielded almost identical results. Therefore, the associations observed in our study between exogenous hormones and lung cancer are not driven by risk factors of or treatment for breast cancer.

One of the key issues in case-control studies is the appropriate choice of controls. In this pooled analysis, four out of six studies enrolled only controls sampled from the underlying populations. Two studies used a mix of population and hospital controls. Risk estimates remained virtually the same after excluding hospital controls. Hence, a major source of selection bias was taken into account. Another potential important source of selection bias is differential participation among cases and controls. Selection bias could occur if participation was associated with both exposure and outcome. Even if its occurrence cannot be completely ruled out, we chose to adjust for education (a strong determinant of hormone use, lung cancer and participation), thus substantially reducing nonresponse bias (Richiardi et al, 2008).

Although information on hormone use was self-reported, recall is unlikely to have occurred differentially for cases and controls because of the lack of knowledge regarding the possible link with lung cancer at the time the studies were conducted.

Data on HRT type were available only for a portion of the study population, and some subgroup analyses might have been influenced by small sample size in a few categories. Finally, although in theory residual confounding by smoking can never be completely excluded, a detailed smoking history was collected that allowed us to adjust for smoking status, intensity, duration and time since quitting.

The OC use has been previously investigated in five casecontrol (Taioli and Wynder, 1994; Kreuzer et al, 2003; Elliott and Hannaford, 2006; Schwartz et al, 2007; Meinhold et al, 2011) and five cohort (Kabat et al, 2007; Weiss et al, 2008; Seow et al, 2009; Baik et al, 2010; Brinton et al, 2011) studies, and most of them did not show an association with lung cancer risk. A reduction in lung cancer risk was observed by Kreuzer et al (2003), but a selection bias due to a particularly poor response among controls cannot be excluded. In the Nurses' Health Study (Baik et al, 2010) the use of OC for $>5$ years was associated with a slightly increased risk mainly among smokers. In the United Kingdom, two large prospective studies have been established in the 1970 s to evaluate health effects among women who have used OC (the RCGP and the Oxford FPA cohort studies). In both studies, the most recent updated mortality (Hannaford et al, 2010; Vessey et al, 2010) and cancer incidence did not reveal increased lung cancer risk when OC ever users were compared with never users.

Oestrogens may be involved in lung carcinogenesis through multiple pathways not yet completely clarified. Oestrogen effects are likely to be mediated by the oestrogen receptors (ERs) $\alpha$ and $\beta$. Oestrogen receptor- $\alpha$ mRNA is expressed at low levels in the lung, 
Table 4. Association between main hormonal factors and lung cancer risk: analyses stratified by smoking status

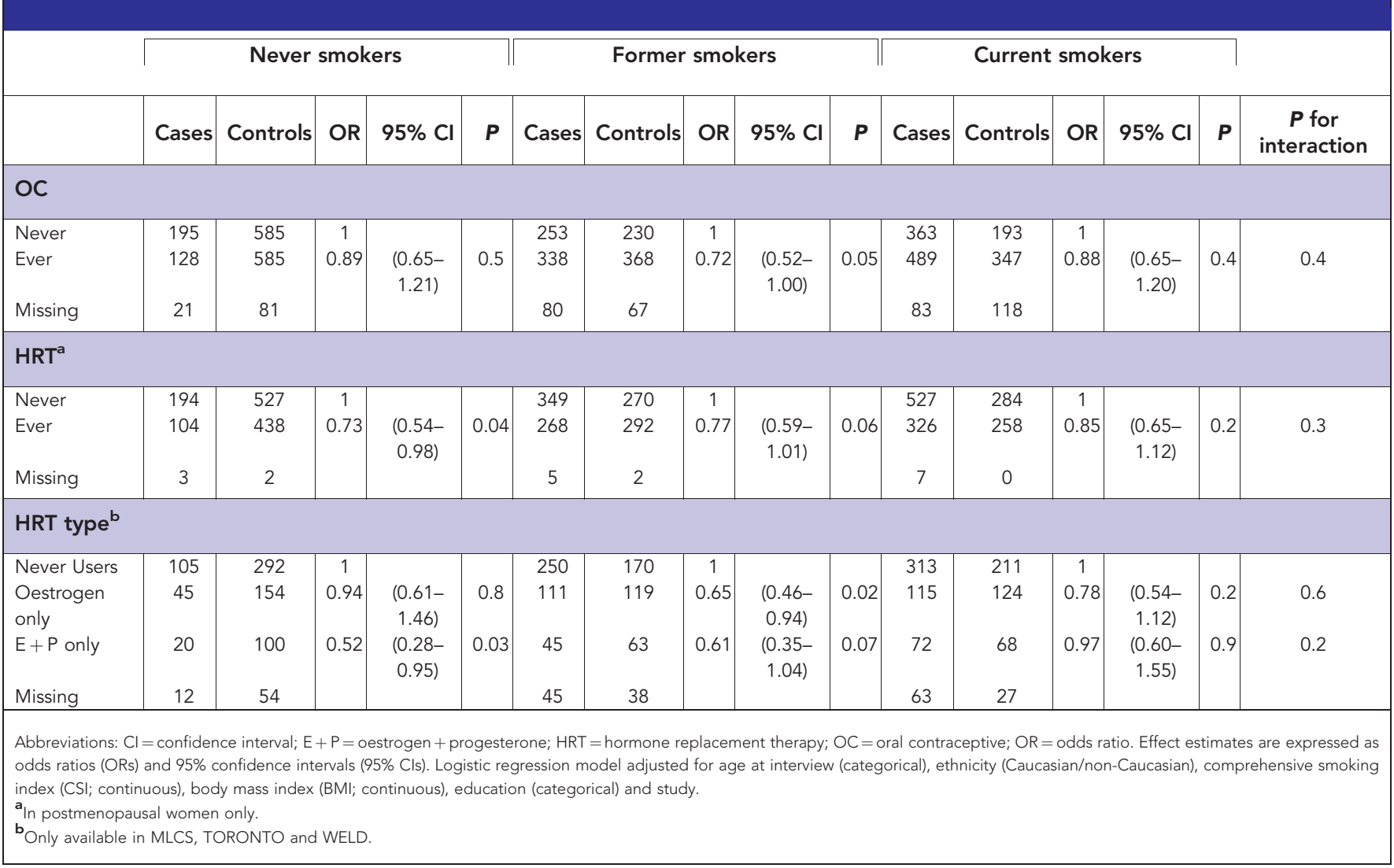

Table 5. Association between main hormonal factors and lung cancer risk across histologic types

\begin{tabular}{|c|c|c|c|c|c|c|c|c|c|c|c|c|c|c|}
\hline & & \multicolumn{4}{|c|}{ Adenocarcinoma } & \multicolumn{4}{|c|}{ Squamous cell carcinoma } & \multicolumn{4}{|c|}{ Small cell carcinoma } & \multirow[b]{2}{*}{$\begin{array}{c}\text { Test for } \\
\text { homogeneity }^{a}\end{array}$} \\
\hline & Controls & Cases & OR & $95 \% \mathrm{Cl}$ & $\boldsymbol{P}$ & Cases & OR & $95 \% \mathrm{Cl}$ & $\boldsymbol{P}$ & Cases & OR & $95 \% \mathrm{Cl}$ & $P$ & \\
\hline \multicolumn{15}{|l|}{ OC } \\
\hline $\begin{array}{l}\text { Never } \\
\text { Ever } \\
\text { Missing }\end{array}$ & $\begin{array}{l}1020 \\
1322 \\
267\end{array}$ & $\begin{array}{l}410 \\
585 \\
79\end{array}$ & $\begin{array}{c}1 \\
0.97\end{array}$ & $\begin{array}{c}(0.79- \\
1.19)\end{array}$ & 0.8 & $\begin{array}{c}122 \\
97 \\
47\end{array}$ & $\begin{array}{c}1 \\
0.53\end{array}$ & $\begin{array}{c}(0.37- \\
0.76)\end{array}$ & 0.001 & $\begin{array}{l}49 \\
35 \\
0\end{array}$ & $\begin{array}{c}1 \\
0.91\end{array}$ & $\begin{array}{c}(0.50- \\
1.65)\end{array}$ & 0.8 & 0.004 \\
\hline \multicolumn{15}{|l|}{$\mathrm{HRT}^{\mathrm{b}}$} \\
\hline $\begin{array}{l}\text { Never } \\
\text { Ever } \\
\text { Missing }\end{array}$ & $\begin{array}{c}1094 \\
995 \\
4\end{array}$ & $\begin{array}{l}545 \\
407 \\
10\end{array}$ & $\begin{array}{c}1 \\
0.79\end{array}$ & $\begin{array}{c}(0.66- \\
0.95)\end{array}$ & 0.01 & $\begin{array}{c}160 \\
90 \\
2\end{array}$ & \begin{tabular}{|c|}
1 \\
0.79
\end{tabular} & $\begin{array}{c}(0.58- \\
1.09)\end{array}$ & 0.2 & $\begin{array}{l}62 \\
15 \\
2\end{array}$ & $\begin{array}{c}1 \\
0.37\end{array}$ & $\begin{array}{l}(0.19- \\
0.71)\end{array}$ & 0.003 & 0.07 \\
\hline $\begin{array}{l}\text { Abbreviati } \\
\text { confidenc } \\
\text { comprehe } \\
{ }^{\text {aWald tes }} \\
\mathbf{b}_{\text {In postm }}\end{array}$ & $\begin{array}{l}\mathrm{Cl}=\text { confid } \\
\text { ervals }(95 \% \\
\text { smoking in } \\
\text { tausal wome }\end{array}$ & $\begin{array}{l}\text { en interva } \\
\text { s). Multin } \\
\text { (CSI; co } \\
\text { only. }\end{array}$ & inou & $\begin{array}{l}\text { ormone re } \\
\text { stic regre } \\
\text { pody mas }\end{array}$ & $\begin{array}{l}\text { emen } \\
\text { mod } \\
\text { ex (B) }\end{array}$ & $\begin{array}{l}\text { nerapy } \\
\text { adjust } \\
\text { contin }\end{array}$ & $\begin{array}{l}\mathrm{C}=\mathrm{o} \\
\text { or as } \\
\text { s), ec }\end{array}$ & $\begin{array}{l}\text { contracept } \\
\text { at interviev } \\
\text { tion (categ }\end{array}$ & $\begin{array}{l}D R=o c \\
\text { tegoric } \\
\text { l) and } s\end{array}$ & $\begin{array}{l}\text { ratio. } \\
\text { ethnic } \\
\text { dy. }\end{array}$ & ct e & $\begin{array}{l}\text { tes are } \\
\text { h/non--C }\end{array}$ & $\begin{array}{l}\text { ressed } \\
\text { CASIAN }\end{array}$ & $\begin{array}{l}\text { dds ratios (ORs) and } \\
\text { oking status (ever/ne }\end{array}$ \\
\hline
\end{tabular}

whereas $\operatorname{ER} \beta$ has been shown to be expressed in both normal and tumour pulmonary tissue (Kaiser et al, 1996; Omoto et al, 2001). The AF- 1 domain of $\operatorname{ER} \beta$ is truncated compared with $\mathrm{ER} \alpha$, and $\mathrm{ER} \beta$ is thus less active in inducing transcriptional activation (Delaunay et al, 2000).

Moreover, the oestrogen receptors $\alpha$ and $\beta$ are expressed in a wide range of immune cells involved in both the innate and adaptive immune response (Cutolo et al, 2010). Oestrogens might therefore be involved in strengthening the immune response against neoplastic cells.

An additional hypothesis is that part of the protective effect exerted by oestrogens might be mediated by interaction with growth factors, in particular epidermal growth factor (EGF). Although EGF is known to be involved in cell growth, protection from apoptosis and angiogenesis, it is possible that ER and EGF pathways are alternatively activated, as the expression of the EGF 
receptor protein was shown to be downregulated in response to oestrogens (Stabile et al, 2005).

Hormone replacement therapy has been shown to decrease insulin-like growth factor 1 (IGF1) (Yu et al, 1999), and low levels of IGF1 have been associated with a reduced risk of lung cancer (Schabath et al, 2004).

In conclusion, our results suggest that exogenous hormones could play a protective role in lung cancer aetiology and find some support from the biological mechanisms underlying lung cancer development. At the same time, the absence of a clear doseresponse relationship urges cautiousness in interpreting the observed association. Moreover, the complex crosstalk between different pathways requires further and large studies to clarify the role of exogenous hormones and the involved mechanisms in lung cancer aetiology.

\section{ACKNOWLEDGEMENTS}

This work was supported by Intramural Research Program of the National Institutes of Health (National Cancer Institute, Division of Cancer Epidemiology and Genetics), Lombardy Region (Environmental Epidemiology Program), CARIPLO Foundation (Milan, Italy) and National Cancer Institute Grant R01CA87895. We express our gratitude to all the study participants and collaborators whose commitment made this pooled analysis possible.

\section{CONFLICT OF INTEREST}

The authors declare no conflict of interest.

\section{REFERENCES}

Andersson T, Alfredsson L, Kallberg H, Zdravkovic S, Ahlbom A (2005) Calculating measures of biological interaction. Eur J Epidemiol 20(7): 575-579.

Baik CS, Strauss GM, Speizer FE, Feskanich D (2010) Reproductive factors, hormone use, and risk for lung cancer in postmenopausal women, the Nurses' Health Study. Cancer Epidemiol Biomarkers Prev 19(10): 2525-2533.

Blackman JA, Coogan PF, Rosenberg L, Strom BL, Zauber AG, Palmer JR, Langenberg P, Shapiro S (2002) Estrogen replacement therapy and risk of lung cancer. Pharmacoepidemiol Drug Saf 11(7): 561-567.

Brenner DR, Hung RJ, Tsao MS, Shepherd FA, Johnston MR, Narod S, Rubenstein W, McLaughlin JR (2010) Lung cancer risk in never-smokers: a population-based case-control study of epidemiologic risk factors. $B M C$ Cancer 10: 285.

Brinton LA, Gierach GL, Andaya A, Park Y, Schatzkin A, Hollenbeck AR, Spitz MR (2011) Reproductive and hormonal factors and lung cancer risk in the NIH-AARP Diet and Health Study cohort. Cancer Epidemiol Biomarkers Prev 20(5): 900-911.

Chen GG, Zeng Q, Tse GM (2008) Estrogen and its receptors in cancer. Med Res Rev 28(6): 954-974.

Chen KY, Hsiao CF, Chang GC, Tsai YH, Su WC, Perng RP, Huang MS, Hsiung CA, Chen CJ, Yang PC, Group GS (2007) Hormone replacement therapy and lung cancer risk in Chinese. Cancer 110(8): 1768-1775.

Chlebowski RT (2009) Menopausal hormone therapy, hormone receptor status, and lung cancer in women. Semin Oncol 36(6): 566-571.

Chlebowski RT, Anderson GL, Manson JE, Schwartz AG, Wakelee H, Gass M, Rodabough RJ, Johnson KC, Wactawski-Wende J, Kotchen JM, Ockene JK, O'Sullivan MJ, Hubbell FA, Chien JW, Chen C, Stefanick ML (2010) Lung cancer among postmenopausal women treated with estrogen alone in the women's health initiative randomized trial. J Natl Cancer Inst 102(18): $1413-1421$.

Clague J, Reynolds P, Sullivan-Halley J, Ma H, Lacey Jr JV, Henderson KD, Ursin G, West D, Chang S, Delclos GL, Du XL, Forman MR, Bernstein L (2011) Menopausal hormone therapy does not influence lung cancer risk: results from the California Teachers Study. Cancer Epidemiol Biomarkers Prev 20(3): 560-564.

Cochran WG (1954) The combination of estimates from different experiments. Biometrics 10(1): 101-129.

Cutolo M, Brizzolara R, Atzeni F, Capellino S, Straub RH, Puttini PC (2010) The immunomodulatory effects of estrogens: clinical relevance in immune-mediated rheumatic diseases. Ann NY Acad Sci 1193: 36-42.

Delaunay F, Pettersson K, Tujague M, Gustafsson JA (2000) Functional differences between the amino-terminal domains of estrogen receptors alpha and beta. Mol Pharmacol 58(3): 584-590.

Donington JS, Colson YL (2011) Sex and gender differences in non-small cell lung cancer. Semin Thorac Cardiovasc Surg 23(2): 137-145.

Egger M, Smith GD, Altman DG (2001) Systematic Reviews in Health Care: Meta-Analysis in Context. 2nd edn, BMJ: London.

Elliott AM, Hannaford PC (2006) Use of exogenous hormones by women and lung cancer: evidence from the Royal College of General Practitioners' Oral Contraception Study. Contraception 73(4): 331-335.

Fritz AG, Percy C, Jack A, Shanmugaratnam K, Sobin L, Parkin DM, Whelan S (2000) International Classification of Diseases for Oncology. 3rd edn, World Health Organization: Geneva, Switzerland.

Greiser CM, Greiser EM, Doren M (2010) Menopausal hormone therapy and risk of lung cancer-Systematic review and meta-analysis. Maturitas 65(3): 198-204.

Hannaford PC, Iversen L, Macfarlane TV, Elliott AM, Angus V, Lee AJ (2010) Mortality among contraceptive pill users: cohort evidence from Royal College of General Practitioners' Oral Contraception Study. BMJ 340: c927.

Heck JE, Andrew AS, Onega T, Rigas JR, Jackson BP, Karagas MR, Duell EJ (2009) Lung cancer in a U.S. population with low to moderate arsenic exposure. Environ Health Perspect 117(11): 1718-1723.

Higgins JP, Thompson SG, Deeks JJ, Altman DG (2003) Measuring inconsistency in meta-analyses. BMJ 327(7414): 557-560.

Hoffmann K, Krause C, Seifert B (2001) The German Environmental Survey 1990/92 (GerES II): primary predictors of blood cadmium levels in adults. Arch Environ Health 56(4): 374-379.

Hulley S, Grady D, Bush T, Furberg C, Herrington D, Riggs B, Vittinghoff E (1998) Randomized trial of estrogen plus progestin for secondary prevention of coronary heart disease in postmenopausal women. Heart and Estrogen/progestin Replacement Study (HERS) Research Group. JAMA 280(7): 605-613.

Jemal A, Bray F, Center MM, Ferlay J, Ward E, Forman D (2011) Global cancer statistics. CA Cancer J Clin 61(2): 69-90.

Kabat GC, Miller AB, Rohan TE (2007) Reproductive and hormonal factors and risk of lung cancer in women: a prospective cohort study. Int J Cancer 120(10): 2214-2220.

Kaiser U, Hofmann J, Schilli M, Wegmann B, Klotz U, Wedel S, Virmani AK, Wollmer E, Branscheid D, Gazdar AF, Havemann K (1996) Steroidhormone receptors in cell lines and tumor biopsies of human lung cancer. Int J Cancer 67(3): 357-364.

Kiyohara C, Ohno Y (2010) Sex differences in lung cancer susceptibility: a review. Gend Med 7(5): 381-401.

Kreuzer M, Gerken M, Heinrich J, Kreienbrock L, Wichmann HE (2003) Hormonal factors and risk of lung cancer among women? Int J Epidemiol 32(2): 263-271.

Leffondré K, Abrahamowicz M, Xiao Y, Siemiatycki J (2006) Modelling smoking history using a comprehensive smoking index: application to lung cancer. Stat Med 25(24): 4132-4146.

Liu Y, Inoue M, Sobue T, Tsugane S (2005) Reproductive factors, hormone use and the risk of lung cancer among middle-aged never-smoking Japanese women: a large-scale population-based cohort study. Int $J$ Cancer 117(4): 662-666.

Meinhold CL, Berrington de Gonzalez A, Bowman ED, Brenner AV, Jones RT, Lacey Jr JV, Loffredo CA, Perlmutter D, Schonfeld SJ, Trivers GE, Harris CC (2011) Reproductive and hormonal factors and the risk of nonsmall cell lung cancer. Int J Cancer 128(6): 1404-1413.

Meireles SI, Esteves GH, Hirata Jr R, Peri S, Devarajan K, Slifker M, Mosier SL, Peng J, Vadhanam MV, Hurst HE, Neves EJ, Reis LF, Gairola CG, Gupta RC, Clapper ML (2010) Early changes in gene expression induced by tobacco smoke: evidence for the importance of estrogen within lung tissue. Cancer Prev Res 3(6): 707-717.

Oh SW, Myung SK, Park JY, Lym YL, Ju W (2010) Hormone therapy and risk of lung cancer: a meta-analysis. J Women Health 19(2): 279-288. 
Omoto Y, Kobayashi Y, Nishida K, Tsuchiya E, Eguchi H, Nakagawa K, Ishikawa Y, Yamori T, Iwase H, Fujii Y, Warner M, Gustafsson JA, Hayashi SI (2001) Expression, function, and clinical implications of the estrogen receptor beta in human lung cancers. Biochem Biophys Res Commun 285(2): 340-347.

Pesatori AC, Carugno M, Consonni D, Caporaso NE, Wacholder S, Tucker M, Landi MT (2013) Reproductive and hormonal factors and the risk of lung cancer: The EAGLE study. Int J Cancer J 132(11): 2630-2639.

Ramnath N, Menezes RJ, Loewen G, Dua P, Eid F, Alkhaddo J, Paganelli G, Natarajan N, Reid ME (2007) Hormone replacement therapy as a risk factor for non-small cell lung cancer: results of a case-control study. Oncology 73(5-6): 305-310.

Richiardi L, Barone-Adesi F, Merletti F, Pearce N (2008) Using directed acyclic graphs to consider adjustment for socioeconomic status in occupational cancer studies. J Epidemiol Commun Health 62(7): e14.

Rodriguez C, Spencer Feigelson H, Deka A, Patel AV, Jacobs EJ, Thun MJ, Calle EE (2008) Postmenopausal hormone therapy and lung cancer risk in the cancer prevention study II nutrition cohort. Cancer Epidemiol Biomarkers Prev 17(3): 655-660.

Rothman KJ (2002) Epidemiology: An Introduction. Oxford University Press: USA.

Schabath MB, Wu X, Vassilopoulou-Sellin R, Vaporciyan AA, Spitz MR (2004) Hormone replacement therapy and lung cancer risk: a case-control analysis. Clin Cancer Res 10(1 Pt 1): 113-123.

Schwartz AG, Wenzlaff AS, Prysak GM, Murphy V, Cote ML, Brooks SC, Skafar DF, Lonardo F (2007) Reproductive factors, hormone use, estrogen receptor expression and risk of non small-cell lung cancer in women. J Clin Oncol 25(36): 5785-5792.

Seow A, Koh WP, Wang R, Lee HP, Yu MC (2009) Reproductive variables, soy intake, and lung cancer risk among nonsmoking women in the Singapore Chinese Health Study. Cancer Epidemiol Biomarkers Prev 18(3): 821-827.
Siegfried JM (2010) Early changes in pulmonary gene expression following tobacco exposure shed light on the role of estrogen metabolism in lung carcinogenesis. Cancer Prev Res 3(6): 692-695.

Slatore CG, Chien JW, Au DH, Satia JA, White E (2010) Lung cancer and hormone replacement therapy: association in the vitamins and lifestyle study. J Clin Oncol 28(9): 1540-1546.

Stabile LP, Lyker JS, Gubish CT, Zhang W, Grandis JR, Siegfried JM (2005) Combined targeting of the estrogen receptor and the epidermal growth factor receptor in non-small cell lung cancer shows enhanced antiproliferative effects. Cancer Res 65(4): 1459-1470.

Taioli E, Wynder EL (1994) Re: Endocrine factors and adenocarcinoma of the lung in women. J Natl Cancer Inst 86(11): 869-870.

Tanko LB, Christiansen C (2004) An update on the antiestrogenic effect of smoking: a literature review with implications for researchers and practitioners. Menopause 11(1): 104-109.

Vessey M, Yeates D, Flynn S (2010) Factors affecting mortality in a large cohort study with special reference to oral contraceptive use. Contraception 82(3): 221-229.

Weiss JM, Lacey Jr JV, Shu XO, Ji BT, Hou L, Yang G, Li H, Rothman N, Blair A, Gao YT, Chow WH, Zheng W (2008) Menstrual and reproductive factors in association with lung cancer in female lifetime nonsmokers. Am J Epidemiol 168(11): 1319-1325.

Yu H, Spitz MR, Mistry J, Gu J, Hong WK, Wu X (1999) Plasma levels of insulin-like growth factor-I and lung cancer risk: a case-control analysis. J Natl Cancer Inst 91(2): 151-156.

This work is published under the standard license to publish agreement. After 12 months the work will become freely available and the license terms will switch to a Creative Commons AttributionNonCommercial-Share Alike 3.0 Unported License.

Supplementary Information accompanies this paper on British Journal of Cancer website (http://www.nature.com/bjc) 